\title{
The Effect of Total Quality Management on University Performance in Jordan
}

\author{
Khaled Alzeaideen ${ }^{1}$ \\ ${ }^{1}$ Faculty Business Administration, Zarqa University, Jordan \\ Correspondence: Dr. Khaled Alzeaideen, Faculty Business Administration, Zarqa University, Jordan.
}

Received: July 30, 2019

Accepted: September 5, 2019

Online Published: October 10, 2019

doi:10.5430/ijfr.v10n6p283

URL: https://doi.org/10.5430/ijfr.v10n6p283

\begin{abstract}
Total Quality Management (TQM) a functioning idea to accomplish incessant performance improvement-is the word of mouth of the 1990s, attracting deep interest among organizations and educational institutions in many countries. Numerous policy-makers truly believe that TQM can improve the performance of their organizations but they did not test it to make sure the effect of TQM. Hence, the purpose of this study is to examine the effect of TQM on university performance in Jordan. This relationship obtains a substantial scholarly attention and several researches have been conducted in the western countries, but none has been conducted in Jordan in the recent year using this variable in a model. A structured survey was conducted and selected 10 public and 10 private universities in Jordan via cluster random sampling. The hypotheses were tested using SEM-AMOS package 22.0 based on resource based theory. Based on the statistical results, TQM has statistically significant effect on university performance in Jordan. Consequently, the findings evoked that there is a dire need to focus on TQM for boosting university performance and its sustainability in Jordan.
\end{abstract}

Keywords: Total Quality Management (TQM), university performance, Structural Equation Modeling (SEM), Jordan

\section{Introduction}

The higher education is a requirement imposed by the transformations in most societies of the developing and developed countries in the world. According to Altahayneh (2014) and Ariff, Zaidin, \&Sulong (2007), universities meet various difficulties and encounters causing from speedy growth in student enrolments, financial crisis, decreasing the number of quality graduates, shortage of competent staff and qualified faculty members, and growing competition among public and private universities. These types of disputed issues encouraged several higher educational institutions to assess the way to deliver facilities to their students. This assessment also encouraged several universities to discover methods to change their administrative processes with the target of increasing efficiency and quality (McMillan, 2016).

According to McMillan (2016), in reaction to the necessity of improvement in the university services and administrative processes, numerous universities have instigated to search various management processes. Ritter (2015) claimed that total quality management is one of the widespread management practice esembraced by countless universities and the appropriateness of total quality management in the educational arena has engrossed the attention of numerous researchers (Sabet, Saleki, Roumi, \&Dezfoulian, 2017; Venkatraman, 2017; Becket \& Brookes, 2016; Kwan, 2016; Currie, Krbec, \& Higgins, 2015; Salameh, Alzyadat, \&Alnsour, 2015; Sirvanci, 2014; Zabadi, 2013). Total quality management is arecognisedarea of research where academics, researchers, and quality practitioners have impacted their ideas on the way to its progress. Santarisi and Tarazi (2018) TQM is correctly described as both a philosophy and set of controlling principles that epitomize the basis of constant developing organizations and it is the method of shifting the necessary culture of an organization and forwarding it toward better service quality. Krajewski et al. (2017) mentioned in their study that TQM is the idea that stresses the ideologies of customer satisfaction, employee participation and unceasing process development for reaching high levels of quality and performance.

Sabet et al. (2017); Venkatraman (2017); Becket \& Brookes (2016); Kwan, (2016); Currie et al. (2015); Salameh et al. (2015) draw attention that higher educational institutions have focussed to TQM with the intention of refining their performance and make available top quality services and programs. So, lots of the previous researches specify a positive effect of TQM on both long-term and short-term performance. According to Brigham (1993) the momentum of TQM has been so spreadable that it swept through manufacturing, then service and health care, and now comes to 
government and higher education. However, considering higher education, it has been much slower than other businesses to grip the TQM philosophy though a number of universities have make an effort to execute it in whole or in part (Elmuti et al., 2016).

\section{Literature Review}

\subsection{Total Quality Management (TQM)}

According to Altahayneh (2014) and Charantimath (2017) Total quality management is a controlling method that pursues to accomplish and put up with long-term organizational achievement by inspiring employees, fulfilling customer desires, admiring societal views and following governmental regulations and laws. Alternative TQM definition was familiarized by Corrigan (1995) who described total quality management as a controlling idea that constructs customer-driven organizations devoted to fulfil customer needs and wants via constant development in the proficiency of the organization and its practices.

Total quality management is more than a philosophy; it can be well-thought-out a suitable outline used in and by organizations to assure a methodical and enduring optimization of the additional value so as to get the most out of the realization of their aims (De Knop, Van Hoecke, \& De Bosscher, 2014). Kolarik (2015); and De Knop et al. (2014), recognize three vital modules of TQM, number one is focus on customer satisfaction, two is unceasing development, and the last one is total participation and dedication. According to Peters (1984), these modules as essential skill packages to step onwards a useful service faced organization. The advantages of TQM can be viewed as the significances of its successful implementation. It has been exposed by numerous academics that the key objective of total quality management is enhancing performance (Currie et al., 2015).

By the way, performance enhancement as the top nexus of estimating TQM benefits. Similarly, it is exposed that accepting TQM has an advantage of upgrading customer satisfaction, better products, services quality and market share (Kwan, 2016). All these are correspondingly reflected as the benefits of TQM as all of them accomplished via TQM. In the same way, improving productivity, operating performance, financial performance and effectiveness are recognized as benefits of TQM (Sabet et al., 2017).

\subsection{University Education in Jordan}

University education in Jordan is acknowledged as a key to transformation and progress and that has begun an upsurge in the demand for its entrance, escorted by a number of confronts. According to Chapman (2011), university in Jordan, meet numerous difficulties, consequential from the economic growth and social changes, advancement of technology, and the globalization of the world economy.

Right now, Jordanian higher education enrolls about 398000 students in 34 universities (including public and private) and 51 community colleges, under the supervision of the Ministry of Higher Education and Scientific Research (Ministry of Higher Education and Scientific Research, 2016). The Higher Education Accreditation Council for both public and private universities is now independent (Chapman, 2011).

In spite of the modification exertions to accomplish high quality education, several universities in Jordan still grapple to assimilate quality to their administration endeavours. Khader (2017) claimed that Jordan has unexploited numerous things on the road to educational superiority. In recent times, some studies have been conducted in Jordan but most of them used qualitative methods in reaction to the claim of numerous researchers for applying total quality management principles in the universities (Sabri\& El-Refae, 2016; Abdel-Qader et al., 2013; Al-Tarrawneh \& Mubasilat, 2011).

\subsection{TQM in University Education}

Total quality management is an emerging idea; it has been widely embraced as a management pattern by lots of organizations globally since its establishment in 1980s (Kanji, Tambi, Wallace, 1999). TQM has its backgrounds in the industrial sector, there has been a solid push for accepting TQM in educational organizations from the stakeholders (Sakthiveland Raju, 2016). Numerous researchers revealed that total quality management has been extensively accepted by both public and private university education (Kanji et al., 1999). Samson and Terziovski (2012) identified that university education should be directed to overall TQM principles by the top administration for superior performance. Motwani, and Kumar (2001), specified that educational organizations had commenced to realize the pressure to change for improvement. These have pretended many challenges operating with the intangible procedures in university education surrounded by the various elements of TQM.

According to Venkatraman (2017), customer attention and frequent improvement are the mainly common viewpoints that have direct attachments for teaching and learning process in university education. However, at the time of applying TQM idea to their universities, some of them thought that participative management programs steer educational quality, 
that may move away from their core process and customer focus (Alzhrani, 2015). Therefore, it is essential for universities to learn from the practices and to focus on their main processes, specially teaching or learning procedure and there must be a systematic appraisal of the performance, which is to be done by TQM (Aminbeidokhti et al., 2016). Kanji et al. (1999) mentioned that TQM has been employed to universities in the UK, USA and in Asian countries such as Japan, South Korea, Malaysia and also in some Arabian countries. However, Altahayneh (2014) mentioned that in Jordan, the public universities were quicker than private universities in embracing TQM. Hence, the researcher focuses on the Jordanian universities as a scope of the current study to see the effect of TQM on its performance.

\subsection{Relationship Between Total Quality Management and Organizational Performance}

Concerning the performance implications of TQM strategy, a significant amount of work reported that the TQM philosophy adoption will consequently provide benefit to every organization (Sallis, 2015). Samson and Terziovski (2012) explored grounded on a number of empirical researchers that the effect of TQM on University Performance cannot be denied. Such applicable to this study, since the organizations under the current study are universities.

Abd-al-Qader (2013) described the prospect of executing the ideas of total quality management at Mutah University. The results of that research revealed that the capability to utilize the total quality management ideas was significantly depended on the extents of leadership, mission of the university, coordination, customer satisfaction, scientific methods of decision-making and overall strategic planning. Sabri and El-Refae (2016) scrutinized the accreditation of BBA program in private universities in Jordan. The results proposed that though the preparations for accreditation in Jordanian private universities were generating certain improvement in deciding and promising quality bench mark in the BBA program, but, they were yet not enough. They suggested that accreditation to be used to all educational institutions in Jordan.

Jaff (2014) examined the intensity of relating Deming ideologies of TQM on faculties of educational sciences in Jordanian private universities from the standpoint of their faculty members. The results presented that Deming ideologies of TQM were almost utilized in the universities of education. The order of these ideologies differ as ordered by Deming and there were no significant differences between faculty responses attributed to gender and experience.

Several evidences have been established justifying the relationship between TQM and university performance in the education sector and where some other studies also shows a weak relationship between TQM and university performance (Sakthivel et al., 2015). Therefore, based on those findings and mixed results, this study proposes the following hypothesis:

H1: There is a significant effect of TQM on University Performance in Jordan.

\subsection{Conceptual Framework of the Study}

This study has been formulated based on Resource Based Theory (RBT) which claims that total quality management is a valuable and intangible resources that lead towards the better university performance. Hence, the constructs under investigation in this study are shown in the following schematic diagram.

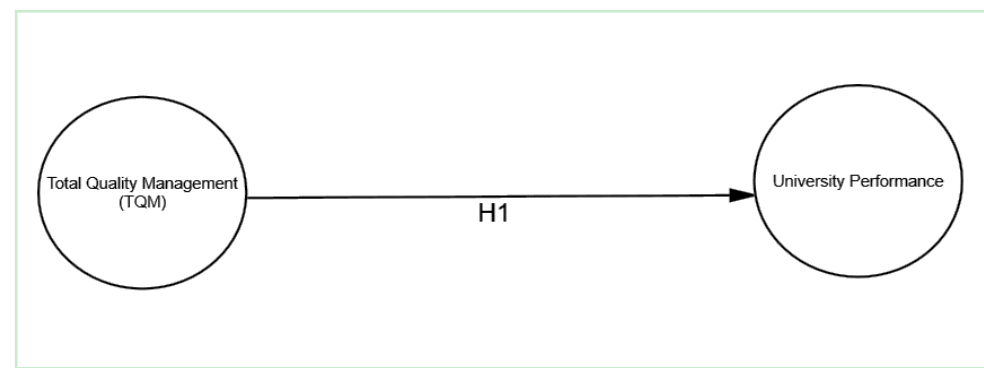

Figure 1. Research framework

\section{Research Methodology}

\subsection{Sampling and Data Collection}

This study is to explore the effects TQM on University performance in Jordan. Therefore, survey was conducted and perceptions of Jordanian university top management were collected to analyze the effect. In this regard a structured survey was conducted using cluster random sampling and selected 10 Public as well as 10 Private universities in 
Jordan. The main ground of selecting 10 Public and 10 Private universities as to minimize the sample bias. Hence, data were collected from the randomly selected deans, deputy deans and professors of various faculties of those public and private universities. After that a total of 180 usable questionnaires were received back.

\subsection{Instrumentation}

This survey included two constructs which are TQM and University Performance. The TQM instrument was adapted and customized from the work of Altahayneh (2014). Whereas, university performance instrument was adapted and customized from the work of Santarisi and Tarazi (2018). Statement items were measured using a ten-point Likert interval scale.

\subsection{Method of Analysisi}

Structural Equation Modelling (SEM) is a second generation method of multivariate analysis technique (Hoque, Awang, Baharu, \& Siddiqui, 2018a; Hoque, Awang, \& Gwadabe, 2018g; Hoque, Awang, \& Salam, 2017a; Hoque, Awang, \& Siddiqui, 017b; Hoque, Awang, Jusoff, Salleh, \& Muda, 2017c; Awang, 2014) thus, the researchers employed SEM so as to keep pace with the advancement in research methodology. In SEM, first run the Confirmatory Factor Analysis (CFA) procedure and after that accomplish the SEM procedure. Hence, this study used AMOS software version 22 for analysis.

\section{Results}

\subsection{Measurement Model}

Under the measurement model of this study found that all the Fitness Indexes (P-Value=.000; RMSEA=.066; $\mathrm{GFI}=.944 ; \mathrm{IFI}=.977 ; \mathrm{CFI}=.977 ; \mathrm{TLI}=.969 ; \mathrm{NFI}=.959 ; \mathrm{RFI}=.945 ; \mathrm{ChiSq} / \mathrm{df}=2.245)$ shown in Figure 2 of the two latent constructs (i.e., TQM and University Performance) have met the requirement as well as signifies a satisfactoryifit to the data and result of all indexesiwas good. Hence, this study achieved the construct validity (Hoque \& Awang, 2019; Hoque, 2018, Hoque, 2018a, Hoque. 2018b; Hoque, Siddiqui, Awang, \& Baharu, 2018f; Hoque, Awang, \& Ghani, 2016; Hoque \& Awang, 2016a; Hoque \& Awang, 2016b; Hoque \& Awang, 2016c; Awang,i2015).

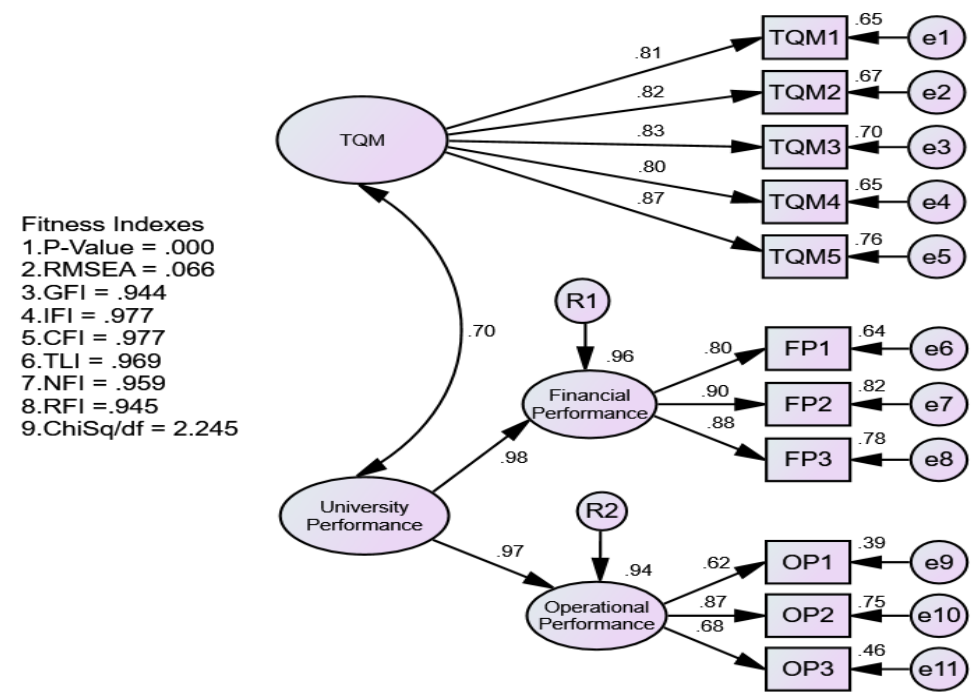

Figure 2. CFA results and the output

Table 1. CFA Results for the measurement model

\begin{tabular}{|c|c|c|c|c|c|}
\hline $\begin{array}{l}\text { Construct } \\
\text { Dimensions }\end{array}$ & and & $\begin{array}{l}\text { Dimensions \& } \\
\text { Items }\end{array}$ & $\begin{array}{l}\text { Factor } \\
\text { Loading }\end{array}$ & $\begin{array}{l}\text { CR } \\
\text { (above 0.6) }\end{array}$ & $\begin{array}{l}\text { AVE } \\
\text { (above 0.5) }\end{array}$ \\
\hline \multirow{2}{*}{\multicolumn{2}{|c|}{ TQM }} & TQM1 & .81 & \multirow{2}{*}{.915} & \multirow{2}{*}{.683} \\
\hline & & TQM2 & .82 & & \\
\hline
\end{tabular}




\begin{tabular}{|c|c|c|c|c|}
\hline & TQM3 & .83 & & \\
\hline & TQM4 & .80 & & \\
\hline & TQM5 & .87 & & \\
\hline \multirow{2}{*}{$\begin{array}{l}\text { University } \\
\text { Performance }\end{array}$} & $\begin{array}{l}\text { Financial } \\
\text { Performance }\end{array}$ & .98 & \multirow{2}{*}{.975} & \multirow{2}{*}{.951} \\
\hline & $\begin{array}{l}\text { Operational } \\
\text { Performance }\end{array}$ & .97 & & \\
\hline \multirow{3}{*}{$\begin{array}{l}\text { Financial } \\
\text { Performance }\end{array}$} & FP1 & .80 & \multirow{3}{*}{.896} & \multirow{3}{*}{.741} \\
\hline & FP2 & .90 & & \\
\hline & FP3 & .88 & & \\
\hline \multirow{3}{*}{$\begin{array}{l}\text { Operational } \\
\text { Performance }\end{array}$} & OP1 & .62 & \multirow{3}{*}{.771} & \multirow{3}{*}{.535} \\
\hline & OP2 & .87 & & \\
\hline & OP3 & .68 & & \\
\hline
\end{tabular}

The factoriloading value for every item of twoiconstructs including sub-constructs that comprise of TQM and University Performance together with CR and AVE for every construct as well as sub-constructs (in Table 1) whichiindicated allatenticonstructs including university performance (i.e., TQM and University performance) have accomplished unidimensionality. All latent constructs have achieved convergent validity, and construct reliability.

Moreover, according toiAwang (2015) one of the criteria of Discriminantivalidity is the correlationibetween exogenous constructs must notiexceed 0.85 . Discriminantivalidity of the constructs is achieved when the diagonal values (i.e. square-root of AVE for the respective constructs) are greater thaniany values in theirirows, and columnsirespectively (Hoque, Awang, Muda, \& Salleh, 2018b; Hoque, Awang, Siddiqui, \& Sabiu, 2018c; Fornell and Larcker, 1981).

Table 2. Discriminant validity index summary

\begin{tabular}{lll}
\hline Constructi & TQM & University Performance \\
\hline TQM & .826 & \\
\hline University Performance & .699 & .975 \\
\hline
\end{tabular}

The correlation value of latent constructs TQM with university performance is .699. Theivalue in diagonaliis greater than the value in its rowiandicolumn in Table 2. So realises thatithe discriminantivalidity is achievedifor theimodel (Hoque, Siddiqui, \& Awang, 2018d; Hoque, Siddiqui, \& Awang, 2018e; Hoque, Gwadabe, \& Rahman, 2017d; Fornell and Larcker, 1981).

\subsection{Structural Model}

The hypothesis H1is supported which is shown in Figure 3. In H1, TQM has aisignificantpositiveieffect on University Performanceiin Jordan ( $\beta=0.589, \mathrm{P}=.001)$. The structuralimodel explains $48.9 \%$ variance in University Performance.

Table 3. Squared multiple correlations $\left(\mathrm{R}^{2}\right)$

\begin{tabular}{ll}
\hline Variable & Estimate $\left(\mathbf{R}^{2}\right)$ \\
\hline University Performance & $\mathbf{0 . 4 8 9}$ \\
\hline
\end{tabular}

Table 3 specifies that the predictors of University Performance explains $48.9 \%$ of itsivariance. In otheriarguments, the error variance of University Performance is about $51.1 \%$ of the varianceiof University Performance. 
Table 4. Standardized regression weights of TQM on university performance

\begin{tabular}{llll}
\hline Variablei & Pathi & Variablei & Estimatei \\
\hline University Performance & $\leftarrow$ & TQM & $\mathbf{0 . 6 9 9}$ \\
\hline
\end{tabular}

Table 4 baseion Figure 3 showed that the effect of TQM on university performance wasi69.9\% while 31.1\% doesinot influence university performance.

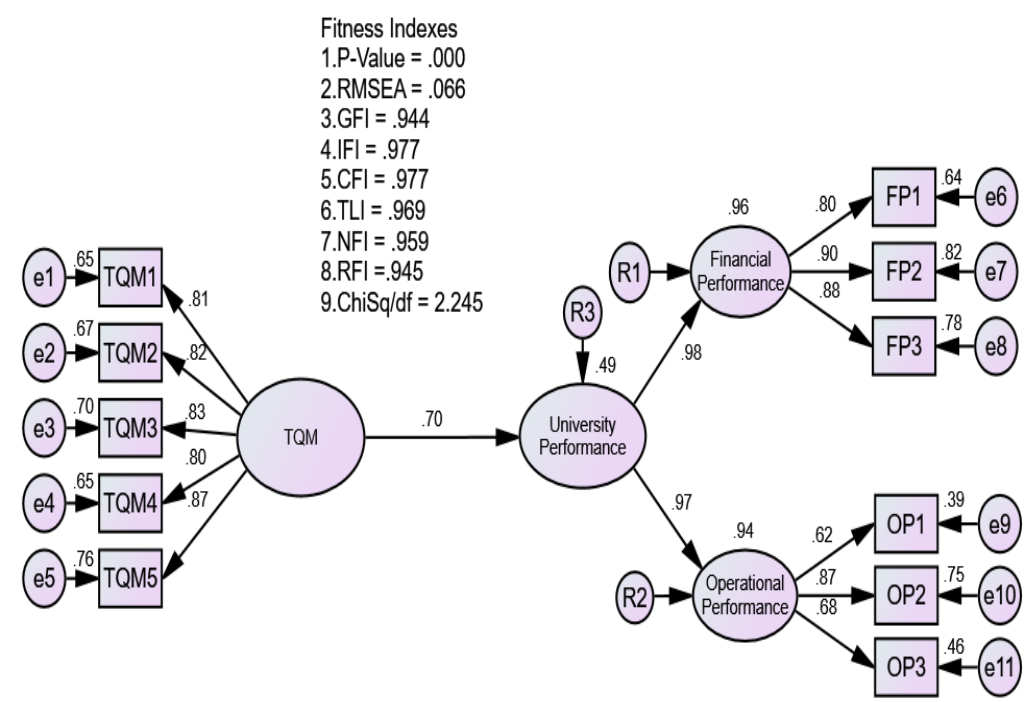

Figure 3. Standardized regression path coefficient

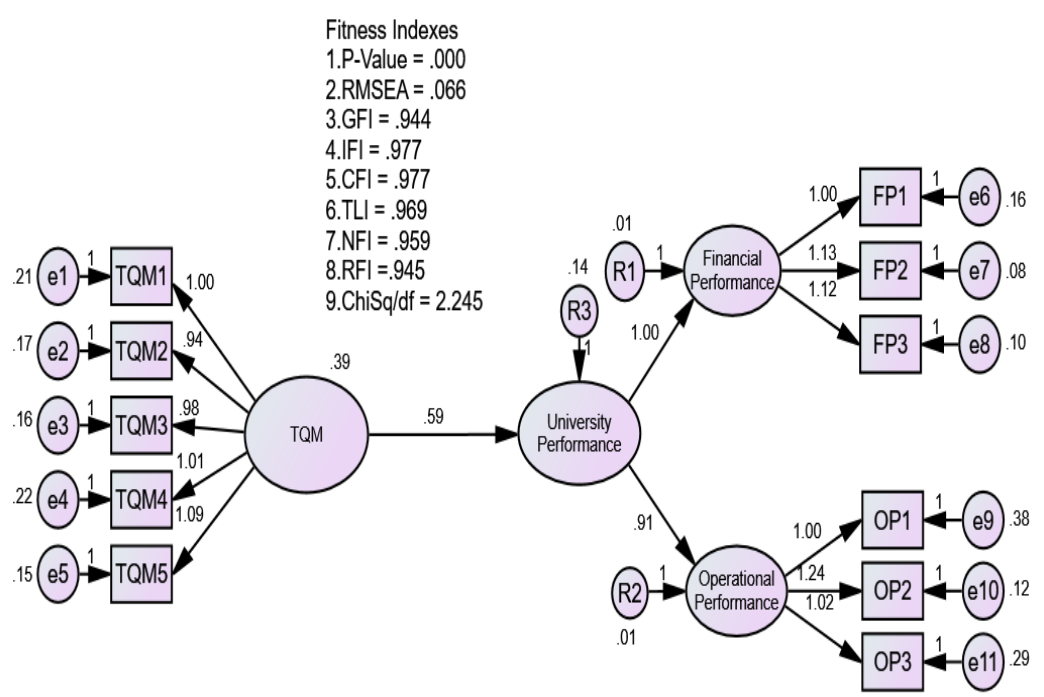

Figure 4. Unstandardized regression path coefficient

The unstandardizediregression weight (i.e. shown in Figure 4) indicatedithat the estimateiof the beta coefficientithatimeasures the effects of TQM on the University Performanceiconstruct. 
Table 5. Regression weight

\begin{tabular}{llllllll}
\hline Variablei & Pathi & Variablei & Estimatei & S.E. & C.R.i & P & iResult \\
\hline $\begin{array}{l}\text { University } \\
\text { Performance }\end{array}$ & $\leftarrow$ & TQM & .589 & 0.056 & 10.442 & $* * *$ & Significant \\
\hline
\end{tabular}

Note: $* * * \mathrm{P}<0.05$

Theihypothesis of this study wasispelt out as: H1, TQM has a significant positive effect on University Performance in Jordan $(\beta=0.589, \mathrm{P}=.001)$. The result in Table 5 showed thatithe level ofisignificance for regression weight indicates that the probability of getting a CR as large as 10.442 in absolute value is 0.05 . In other words, the effects of TQM construct on University Performance construct is highly significant. Hence, ithis research suggested thatithere is a straightforward need to give more attention on TQM for better university performance in Jordan and also toihelp in the national GDP of Jordan through proper exploitation of TQM.

\section{Implications of the Study}

This study has widened our perception pertaining to RBV and outlining the indispensable role of resources as TQM as well as this study is the extension of earlier studies about the effects of TQM on University Performance. This study has also outlined that TQM is significant for University Performance prediction. This, thus, sheds light of scholars of TQM as well as education arena to understand what further empirical associations they could possibly bring towards the university performance and its sustanability. Similarly, the findings highlight an important arena for TQM to focus and unleash how through effective TQM, university can gain better performance. Correspondingly, from this study, policy makers as well as all related stakeholders can get guidelines for policy or decision making regarding university management in Jordan.

\section{Conclusion}

The paper highlights and scrutinizes the effect of TQM on University Performance in Jordan. The significant conclusion from this study is that TQM has a positive and highly significant effect on Jordanian university performance. Hence, from the existing literature as well as this study, it can be explicit that TQM can clout the success, survival and university performance in Jordan. Further study on TQM could provide information as to what can mediate or moderate the relationship between TQM and Jordanian university performance. Although, this study confirmed the role of TQM as an important fact for university strategy, additional research is also desired to enhance the understanding of this critical TQM constructs as well as to determine other measures of university performance and assimilate them into TQM model. Academician or scholars can conduct more research from other sides of TQM as to see how education sector can help to adopt TQM in winning the rivalry in the competitive world economy.

\section{References}

Abdel-Qader, M. A., Abu Quleh, M., Almahyra, M., \& Hindawi, W. A. (2013). The total quality management in the Jordanian universities. European Journal of Business and Management, 5(9), 1-12.

Altahayneh, Z. L. (2014). Implementation of Total Quality Management in Colleges of Physical Education in Jordan. International Journal of Business and Social Science, 5(3), 109-117.

Al-Tarawneh, H. A., \& Mubaslat, M. M. (2011). The implementation of total quality management (TQM) on the higher educational sector in Jordan. International Journal of Industrial Marketing, 1(1), 1-10.

Al-Zahrani, A. M. (2015). From passive to active: The impact of the flipped classroom through social learning platforms on higher education students' creative thinking. British Journal of Educational Technology, 46(6), 1133-1148. https://doi.org/10.1111/bjet.12353

Aminbeidokhti, A., Jamshidi, L., \& Hoseini, A.M. (2016). The effect of the total quality management on organizational innovation in higher education mediated by organizational learning. Studies in Higher Education, 41(7), 1153-1166. https://doi.org/10.1080/03075079.2014.966667

Ariff, M. S., Zaidin, N., \& Sulong, N. (2007). Total quality management implementation in higher education: Concerns and challenges faced by the faculty. Paper presented at the 12thInternational Conference on ISO 9000 and TQM. Taiwan, RoC.

Awang, Z. (2014). A Handbook on SEM for Academicians and Practitioners: the step by step practical guides for the beginners. Bandar BaruBangi: MPWS Rich Resources. 
Awang, Z. (2015). SEM made simple: A Gentle Approach to Learning Structural Equation Modeling. Bandar BaruBangi: MPWS Rich Resources.

Awang, Z., Afthanorhan, A., Mohamad, M., \& Asri, M. A. M. (2015a). An evaluation of measurement model for medical tourism research: the confirmatory factor analysis approach. International Journal of Tourism Policy, 6(1), 29-45. https://doi.org/10.1504/IJTP.2015.075141

Becket, N., \& Brookes, M. (2016). Evaluating quality management in university departments. Quality Assurance in Education, 14(2), 123-142. https://doi.org/10.1108/09684880610662015

Brigham, S. E. (1993). TQM: Lessons We Can Learn from Industry. Change, 25(3), 42-46. https://doi.org/10.1080/00091383.1993.9938458

Chapman, R. (2011). Jordan Fiscal Reform II Project: Education public expenditures. Working paper (Order No. EEM-I-0807-00009-00). USAID/Jordan Economic Growth Office.

Charantimath, P. M. (2017). Total quality management. Delhi, India: Pearson Education Pte. Ltd.

Corrigan, J. (1995). The art of TQM. Quality Progress, 28(7), 61-64.

Currie, D. M., Krbec, D., \& Higgins, J. (2015) Creating a quality assurance system for Croatian higher education. Higher Education in Europe, 30(1), 53-65. https://doi.org/10.1080/03797720500088103

De Knop, P., Van Hoecke, J., \& De Bosscher, V. (2014). Quality management in sports clubs. Sport Management Review, 7(1), 57-77. https://doi.org/10.1016/S1441-3523(04)70045-5

Elmuti, D., Kathawala, K., \& Manippallil, M. (2016). Are total quality management programmes in higher education worth the effort?. International Journal of Quality and Reliability Management, 13(6), 29-44. https://doi.org/10.1108/02656719610124244

Fornell, C., \& Larcker, D. F. (1981), Structural equation models with unobservable variables and measurement error: Algebra and statistics. Journal of Marketing Research, 18(3), 328-388. https://doi.org/10.1177/002224378101800313

Hoque, A. S. M. M. (2018). Digital Device Addiction Effect on Lifestyle of Generation Z in Bangladesh. Asian People Journal (APJ), 1(2), 21-44.

Hoque, A. S. M. M. (2018a). The effect of entrepreneurial orientation on Bangladeshi SME performance: Role of organizational culture. International Journal of Data and Network Science, 2(1), 1-14. https://doi.org/10.5267/j.ijdns.2018.7.001

Hoque, A. S. M. M. (2018b). Does government support policy moderate the relationship between entrepreneurial orientation and Bangladeshi SME performance? A SEM approach. International Journal of Business Economics and Management Studies, 6(3), 37-59.

Hoque, A. S. M. M., \& Awang, Z. (2016a). The Sway of Entrepreneurial Marketing on Firm Performance: Case of Small and Medium Enterprises (SMEs) in Bangladesh, pp. 174-194. Terengganu International Business and Economics Conference (TiBEC-V), Terengganu, Universiti Teknologi Mara (UiTM).

Hoque, A. S. M. M., \& Awang, Z. (2016b). Exploratory Factor Analysis of Entrepreneurial Marketing: Scale Development and Validation in the SME context of Bangladesh, pp. 20-22. International Social Sciences and Tourism Research Conference, Terengganu, UniSZA.

Hoque, A. S. M. M., \& Awang, Z. (2016c, October 8-10). The Impact of Marketing Strategy on Small and Medium Scale Enterprises (SMEs): Case Study in Bangladesh. International Postgraduate Research Conference (IPRC 2016), Universiti Sultan Zainal Abidin (UniSZA), Gong Badak Campus, Kuala Terengganu, Malaysia.

Hoque, A. S. M. M., \& Awang, Z. (2019). Does gender difference play moderating role in the relationship between entrepreneurial marketing and Bangladeshi SME performance?. Accounting, 5(1), 35-52. https://doi.org/10.5267/j.ac.2018.6.001

Hoque, A. S. M. M., Awang, Z., \& Ghani, N. A. (2016, October 6-8). Conceptual Model for Quality of Life in the Perspective of Social Entrepreneurship. International Conference on Science, Engineering, Management and Social Science (ICSEMSS 2016), Universiti Teknologi Malaysia (UTM), Johor Bahru, Malaysia.

Hoque, A. S. M. M., Awang, Z., \& Gwadabe, U. M. (2018g). The Effect of Entrepreneurial Marketing on Bangladeshi SME performance and the Role of Organizational Culture: A Structural Equation Modelling. Journal of Management and Operation Research, 1, 1-21. 
Hoque, A. S. M. M., Awang, Z., \& Salam, S. (2017a, September 21-22). The Effects of Relationship Marketing on Firm Performance: Small and Medium Enterprises (SMEs) in Bangladesh, 1st International Conference on Business and Management (ICBM-2017), BRAC Business School (BBS), BRAC University, Dhaka, Bangladesh.

Hoque, A. S. M. M., Awang, Z., \& Siddiqui, B. A. (2017b). Technopreneurial Intention among University Students of Business Courses in Malaysia: A Structural Equation Modeling. International Journal of Entrepreneurship and Small \& Medium Enterprise (IJESME), 4, 1-16.

Hoque, A. S. M. M., Awang, Z., Baharu, S. M. A. T., \& Siddiqui, B.A., (2018a, July). Upshot of Generation 'Z' Entrepreneurs' E-lifestyle on Bangladeshi SME Performance in the Digital Era. International Journal of Entrepreneurship and Small \& Medium Enterprise (IJESME), 5, 97-118.

Hoque, A. S. M. M., Awang, Z., Jusoff, K., Salleh, F., \& Muda, H. (2017c). Social Business Efficiency: Instrument Development and Validation Procedure using Structural Equation Modelling. International Business Management, 11(1), 222-231.

Hoque, A. S. M. M., Awang, Z., Muda, H., \& Salleh, F. (2018b). Ramification of crowdfunding on Bangladeshi entrepreneur's self-efficacy. Accounting, 4(4), 129-138. https://doi.org/10.5267/j.ac.2018.4.001

Hoque, A. S. M. M., Awang, Z., Siddiqui, B. A., \& Sabiu, M.S. (2018c). Role of Employee Engagement on Compensation System and Employee Performance Relationship among Telecommunication Service Providers in Bangladesh. International Journal of Human Resource Studies, 8(3), 19-37. https://doi.org/10.5296/ijhrs.v8i3.13081

Hoque, A. S. M. M., Gwadabe, U. M., \& Rahman, M. A. (2017d). Corporate Entrepreneurship Upshot on Innovation Performance: The Mediation of Employee Engagement. Journal of Humanities, Language, Culture and Business, 1(6), 54-67.

Hoque, A. S. M. M., Siddiqui, B. A., \& Awang, Z. (2018d, July). Technopreneurial Competency Effect on Technology-based SME Performance: A Structural Equation Modelling on Bangladeshi SMEs. International Journal of Entrepreneurship and Small \& Medium Enterprise (IJESME), 5, 55-73.

Hoque, A. S. M. M., Siddiqui, B. A., \& Awang, Z. (2018e, May 12-13). Technopreneurial Competencies Effects on Bangladeshi SME Performance: A Structural Equation Modeling. 2nd ASIA International Multidisciplinary Conference (AIMC 2018), Faculty of Management, Universiti Teknologi Malaysia (UTM), Johor Bahru, Malaysia.

Hoque, A. S. M. M., Siddiqui, B. A., Awang, Z., \& Baharu, S. M. A. T. (2018f). Exploratory Factor Analysis of Entrepreneurial Orientation in the Context of Bangladeshi Small and Medium Enterprises (SMEs). European Journal of Management and Marketing Studies, 3(2), 81-94.

Jaff, N. (2014). The degree of applying Deming principles of Total Quality Management on faculties of educational sciences in private Jordanian universities from the viewpoint of their faculty members. Unpublished Master thesis, Middle East University, Amman, Jordan.

Kanji, G. K., Tambi, A. A., \& Wallace, W. (1999). A comparative study of quality practices in higher education institution is the US and Malaysia. Total Quality Management, 10(3), 357-371. https://doi.org/10.1080/0954412997884

Khader, F. (2017). Strategies and roadmap for effective higher education in reform in Jordan. ICET Conference, 1(1), 1 -10. ICET, Muscat, Oman.

Kolarik, W. (2015). Creating quality: Concepts, systems, strategies, and tools. New York: McGraw-Hill.

Krajewski, L., Ritzman, L., \& Malhotra, M. (2017). Operations Management (8th ed.). Prentice Hall, New Jersey.

Kwan, P. Y. (2016). Application of total quality management in education: retrospect and prospect. International Journal of Educational Management, 10(5), 25-35. https://doi.org/10.1108/09513549610146114

McMillan, J. M. (2016). Total quality management in higher education: A study of senior administrators" perceptions about total quality management in institutions of higher education in Ohio. Unpublished doctoral dissertation, Kent State University, Ohio, USA.

Motwani, J., \& Kumar, A. (2001). The need for implementing total quality management in education. International Journal of Educational Management, 11(3), 131-135. https://doi.org/10.1108/09513549710164023 
Ritter, J. M. (2015). The applicability of total quality management to higher education: A comparative study of perceptions of community college chief academic officers and chief financial officers. Unpublished doctoral dissertation, Kent State University, Ohio, USA.

Sabet, H., Saleki, Z., Roumi, B., \& Dezfoulian, A. (2017). A study on total quality management in higher education industry in Malaysia. International Journal of Business and Social Science, 3(17), 208-215.

Sabri, H. A. \& El-Refae, G. A. (2016). Accreditation in higher business education in the private sector: The case of Jordan. Journal of Marketing for Higher Education, 16(1), 47-76. https://doi.org/10.1300/J050v16n01_03

Sakthivel, P. B., \& Raju, R. (2006). Conceptualizing total quality management in engineering education and developing a TQM educational excellence model. Total Quality Management and Business Excellence, 17(7), 913-934. https://doi.org/10.1080/14783360600595476

Salameh, R. S., Alzyadat, M. A., \& Alnsour, J. A. (2015). Implementation of (TQM) in the faculty of planning and management at Al-Balqa Applied University. International Journal of Business and Management, 6(3), 194-207.

Sallis, E. (2015). Total Quality Management in Education. Kogan Page, London. https://doi.org/10.4324/9780203417010

Samson, D., \& Terziovski, M. (2012). The relationship between total quality management practices and operational $\begin{array}{lllll}\text { performance. Journal of } & \text { Operations }\end{array}$ https://doi.org/10.1016/S0272-6963(98)00046-1

Santarisi, N. S., \& Tarazi, A. H. (2018). The Effect of TQM Practices on Higher Education Performance: The Faculty of Engineering and Technology at the University of Jordan as a Case Study. Dirasat. Engineering Sciences, 35(2), 84-96.

Sirvanci, M. B. (2004). Issues for TQM implementation in higher education. The TQM Magazine, 16(6), 382-386. https://doi.org/10.1108/09544780410563293

Venkatraman, S. (2017). A framework for implementing TQM in higher education programs. Quality Assurance in Education, 15(1), 92-112. https://doi.org/10.1108/09684880710723052

Zabadi, A. M. (2013). Implementing total quality management (TQM) on the higher education institutions: A conceptual model. Journal of Finance and Economics, 1(1), 42-60. https://doi.org/10.12735/jfe.v1i1p42 